\title{
Study of Correlation between APGAR Score and Cord Blood Glucose Level of Neonates at Tertiary Care Hospital
}

\author{
Karthik $\mathbf{S}^{1}$, Preethi R $\mathbf{M}^{1}$, Kumar G V \\ ${ }^{1}$ Postgraduate Student, Department of Pediatrics, Sri Siddhartha Medical College, Sri Siddhartha Academy of Higher Education, Tumkur, Karnataka, India, \\ ${ }^{2}$ Professor, Department of Pediatrics, Sri Siddhartha Medical College, Sri Siddhartha Academy of Higher Education, Tumkur, Karnataka, India.
}

\section{Abstract}

Background: Cord blood biochemical parameter reflects the status of neonate. APGAR score following birth is used for evaluation of the neonate. There is limited data regarding the correlation between APGAR score and cord blood sugar levels. Subjects and Methods: Glucose Oxidase Peroxidase method was used for measuring cord blood sugar levels of 250 randomly selected consecutive samples. At 1 minute and 5 minutes of life the APGAR scores of the newborns were assessed by a single person in order to avoid subjective variability. The collected data was analyzed using the SPSS software. Mothers with gestational diabetes mellitus and overt diabetes were excluded from the study. Result: The mean age of the mothers in the study population was 22.86 years \pm 3.465 (SD). The mean blood glucose level in the maternal blood was $88.16 \mathrm{mg} / \mathrm{dl} \pm 10.675(\mathrm{SD})$. The vaginal deliveries were $60.6 \%$ and Lower Uterine Caesarean Sections were $39.4 \%$. The cord blood glucose level had a mean value of $92.48 \mathrm{mg} / \mathrm{dl} \pm 21.005$ (SD). The mean APGAR scores after 1 minute and 5 minutes of birth were found to be $4.82 \pm$ 1.42 (SD) and $7.01 \pm 1.68$ (SD) respectively. Conclusion: The study showed no correlation with cord blood sugar levels and APGAR scores calculated at 1 minute and 5 minutes of life. The study found that neonates were free from complications if the cord blood sugar levels were around $87 \mathrm{mg} / \mathrm{dl}$.

Keywords: Cord blood, APGAR, Neonate.

Corresponding Author: Dr. Kumar G V, Professor of paediatrics, Sri Siddhartha Medical College, Sri Siddhartha Academy of Higher Education, Tumkur, Karnataka, India. PIN- 572107.

Email: kumargowripura@gmail.com

Received: January 2020

Accepted: January 2020

\section{Introduction}

Labor is a stressful situation to both the mother and fetus. During labor the presence of fatigue, pain, physiologic alterations and the maternal anxiety, stresses the mother and increases the maternal catecholamines. This also increases fetal catecholamine levels up to ten fold in comparison to pre-labor levels. Both the human and the animal studies have shown that the catecholamine release has a profound difference in different modes of deliveries. Particularly, the production of catecholamines is comparatively higher during the normal vaginal delivery than during cesarean section, this can be explained by the increased stress in vaginal delivery. This labor induced fetal catecholamine surge is presumed to provide the neonate with an important mechanism of adaptation to the extra-uterine environment. Hence newborns delivered via normal vaginal delivery have increased level of blood glucose than their counterparts delivered through elective cesarean section because of increased catecholamines release. This maybe resulted from the hyperglycemic effect of the increased catecholamine release which promote glycogenolysis. ${ }^{[1]}$ Primary substrate for the brain is glucose and its consumption by the brain cells is high. Hence, neurons and glial cells are easily susceptible to hypoglycemia. The most vulnerable areas of the brain are the parieto-occipital regions of the cerebral cortex. Less commonly involved are neurons of caudate nucleus, putamen and hippocampus. Disturbances in myelination might occur due to glial injury. neonatal seizure might occur due to unrecognized postnatal hypoglycemia. Fortunately, in most of these neonates, the hypoglycemia is transient and asymptomatic. However, if the neonates fail to achieve normoglycemia and diagnosis is missed, it may become symptomatic and can suffer long term complications due to cerebral injury. ${ }^{[2]}$

In 1952, Virginia APGAR proposed the APGAR score for evaluating the physical condition of newborns shortly after delivery. This scoring system encouraged delivery-room personnel to pay close attention to the newborn and was rapidly adopted in delivery rooms throughout the world. Each of five easily identifiable characteristics are - heart rate, reflex irritability, respiratory effort, muscle tone, and color - is assessed and assigned a value of 0 to 2 . The score is the total sum of the five components and a score of 7 or higher indicates that the baby's condition is good to excellent. The APGAR score is determined at one and five minutes after delivery and is therefore a rapid way to 
evaluate the physical condition of newborn. Of the two scores, the five-minute score has come to be regarded as the better predictor of survival in infancy. ${ }^{[3]}$

Table 1: Apgar score ${ }^{[4]}$
\begin{tabular}{|l|l|l|l|l|}
\hline \multirow{2}{*}{ Sign } & \multicolumn{1}{c|}{$\mathbf{1}$} & \multicolumn{1}{c|}{$\mathbf{2}$} & \multicolumn{1}{c|}{ SCORE } \\
\cline { 2 - 5 } & \multicolumn{1}{|c|}{$\begin{array}{l}\text { Appearance (skin } \\
\text { colour) }\end{array}$} & $\begin{array}{l}\text { Normal over entire } \\
\text { body }\end{array}$ & $\begin{array}{l}\text { Normal } \\
\text { except } \\
\text { extremities }\end{array}$ & $\begin{array}{l}\text { Cyanotic } \\
\text { or pale all } \\
\text { over }\end{array}$ \\
\hline P & Pulse(heart rate) & $>100 \mathrm{bpm}$ & >100 bpm & $>100 \mathrm{bpm}$ \\
\hline G & $\begin{array}{l}\text { Grimace } \\
\text { response(reflexes) }\end{array}$ & $\begin{array}{l}\text { Grimace } \\
\text { response(reflexes) }\end{array}$ & $\begin{array}{l}\text { Sneezes, } \\
\text { coughs, } \\
\text { pulls away }\end{array}$ & $\begin{array}{l}\text { Grimaces } \\
\text { No } \\
\text { response }\end{array}$ \\
\hline A & $\begin{array}{l}\text { Activity (muscle } \\
\text { tone) }\end{array}$ & $\begin{array}{l}\text { Activity (muscle } \\
\text { tone) }\end{array}$ & $\begin{array}{l}\text { Active } \\
\text { Arms and } \\
\text { legs flexed }\end{array}$ & Absent \\
\hline R & $\begin{array}{l}\text { Respiration } \\
\text { (breathing rate and } \\
\text { effort) }\end{array}$ & Good, crying & $\begin{array}{l}\text { Slow, } \\
\text { irregular }\end{array}$ & Absent \\
\hline
\end{tabular}

Cord blood biochemical parameter reflects the status of neonate. Foetal distress is assessed by measuring cord blood lactate. ${ }^{[5]}$ The adiposity in children can be predicted with adiponectin and leptin levels in the cord blood. The cord blood samples can also detect infections. ${ }^{[6,7]}$ APGAR score following birth is used for evaluation of the neonate. ${ }^{[8-10]}$ Many studies have proved significant correlation between the APGAR score and the foetal $\mathrm{pH}$ and also between the foetal $\mathrm{pH}$ and umbilical artery blood sugar level. ${ }^{[11]}$ But not much literature was available in establishing the Correlation between the APGAR and the cord blood sugar level score. The aim of the current study was to find the correlation between the APGAR score and cord blood glucose level.

\section{Subjects and Methods}

The present study was done on 250 consecutive samples of cord blood selected randomly in a period of one year, at a tertiary-care centre. Naegele's formula was used to calculate the period of gestation from last menstrual period. Maternal details of the blood pressure, haemoglobin and the maternal blood sugar levels were collected. Mothers were selected randomly and monitored throughout the labour. Following delivery $2.5 \mathrm{ml}$ of cord blood was collected in the operation theatre or labour room. Standard Glucose Oxidase Peroxidase (GOD-POD) method was used for cord blood sugar estimation. The commercially available reagents were used and at $540 \mathrm{~nm}$ wave length colorimetric reading was noted.

The newborns were monitored after the delivery. Data regarding the type of delivery, neonates gender, birth weight and presence of foetal distress were noted. At 1 minute of life and at 5 minutes of life after birth the APGAR scores of the newborns were assessed and recorded by a single person in order to avoid subjective variability. Mothers with gestational diabetes mellitus and overt diabetes were excluded from the study and the neonates with congenital anomalies were also excluded. With the SPSS software, the statistical analysis was done and data was analyzed using Student's t-test, Pearson's correlation and ROC curves.

\section{Results}

The mean age of the mothers in the study population was 22.86 years \pm 3.465 (SD) (range 18 to 36 years). The mean haemoglobin concentration in the maternal blood was $10.65 \mathrm{gm} \% \pm 1.802$ (SD) with a minimum value of $7.4 \mathrm{gm} \%$ and a maximum value of $13.8 \mathrm{gm} \%$. The mean systolic and diastolic blood pressures of the study population were $130 \mathrm{~mm}$ of $\mathrm{Hg} \pm 15.405$ (SD) (range 170 to $90 \mathrm{~mm} \mathrm{Hg}$ ) and $85 \pm 12.1 \mathrm{~mm} \mathrm{Hg}$ (range 100 to $60 \mathrm{~mm}$ of $\mathrm{Hg}$ ) respectively. In the current study $56 \%$ of the study population were primigravida and $44 \%$ were multigravida. The mean blood glucose level (random) in the maternal blood was $88.16 \mathrm{mg} / \mathrm{dl} \pm$ 10.675 (SD) (range 128 to $72 \mathrm{mg} / \mathrm{dl}$ ). Of all the cases, the vaginal deliveries were $60.6 \%$ and Lower Uterine Caesarean Sections were $39.4 \%$. The mean birth weight of the neonates was $2.58 \mathrm{~kg} \pm 0.48$ (SD) (range 1.52 to $3.84 \mathrm{~kg}$ ).

The mean fetal maturity, that is gestational age, at birth, was found to be 37.20 weeks \pm 2.452 (SD) (range 41 to 29 weeks). The cord blood glucose level had a mean value of $92.48 \mathrm{mg} / \mathrm{dl} \pm 21.005$ (SD)(range 52 to $139 \mathrm{mg} / \mathrm{dl})$. The mean APGAR scores after 1 minute and 5 minutes of birth were found to be $4.82 \pm$ 1.42 (SD) (range 7 to 1) and $7.01 \pm 1.68$ (SD) (range 10 to 1 ) respectively. At 1 minute of birth, only $2.5 \%$ of the neonates had an APGAR score of 7, which was the cut off for considering the infants as normal. $36.6 \%$ and $26.6 \%$ of the neonates had APGAR scores of 6 and 5 respectively. $3.1 \%$ had the lowest possible value of 1 . At 5 minutes of birth, $67 \%$ of the neonates had an APGAR score of 7 or above, of which $38.6 \%$ had a score of 8. APGAR scores which were as high as 10 and as low as 1 were also found. Among the 250 neonates which were studied, $73(29.2 \%)$ had acute or chronic fetal distress which was identified by the meconium stained liquor and the fetal bradycardia.

Table 2: Shows maternal parameters at the time of delivery

\begin{tabular}{|l|l|l|l|l|}
\hline $\mathbf{n = 2 5 0}$ & Min & Max & Mean & $\begin{array}{l}\text { Std. } \\
\text { Deviation }\end{array}$ \\
\hline Maternal Age (years) & 18 & 36 & 22.86 & 3.465 \\
\hline Maternal Haemoglobin \% & 7.4 & 13.8 & 10.65 & 1.802 \\
\hline $\begin{array}{l}\text { Maternal Systolic Blood } \\
\text { Pressure (mm of Hg) }\end{array}$ & 90 & 170 & 130.50 & 15.405 \\
\hline $\begin{array}{l}\text { Maternal Diastolic Blood } \\
\text { Pressure (mm of Hg) }\end{array}$ & 60 & 100 & 85.25 & 12.100 \\
\hline $\begin{array}{l}\text { Maternal Blood sugar } \\
\text { (mg/dl) }\end{array}$ & 72 & 128 & 88.16 & 10.675 \\
\hline
\end{tabular}

On the basis of APGAR score at 5 minutes of life the newborns were divided into two groups based on APGAR score of seven or above and score of six or less. The applied independent t-test for equality of the means, showed no 
statistical difference in the mean cord blood sugar levels between these two divided groups. Similarly, there was no statistical significance of APGAR score at $1 \mathrm{~min}$ of life. Thus, the study showed no correlation between the two parameters. No correlation was found between cord blood sugar levels and fetal maturity, as the Pearson's co-efficient was much less than zero ( $r=$ minus 0.0290). The weights of the babies at birth had an r-value of minus 0.075 , which excluded any positive correlation with the cord blood sugar level.

\begin{tabular}{|c|c|c|c|c|}
\hline $\mathrm{n}=\mathbf{2 5 0}$ & Min & $\operatorname{Max}$ & Mean & $\begin{array}{l}\text { Std. } \\
\text { Deviation }\end{array}$ \\
\hline Birth weight $(\mathrm{kg})$ & 1.52 & 3.84 & 2.58 & 0.480 \\
\hline Fetal maturity (weeks) & 29 & 41 & 37.20 & 2.452 \\
\hline $\begin{array}{l}\text { Cord blood glucose level } \\
(\mathrm{mg} / \mathrm{dl})\end{array}$ & 52 & 139 & 92.48 & 21.005 \\
\hline 1minute APGAR score & 1 & 7 & 4.82 & 1.420 \\
\hline 5minutes APGAR score & 1 & 10 & 7.01 & 1.680 \\
\hline
\end{tabular}

Table 4: Shows correlation between APGAR Score and cord blood glucose.

\begin{tabular}{|l|l|l|l|l|}
\hline \multicolumn{1}{|c|}{$\begin{array}{c}\text { Category of } \\
\text { APGAR Score }\end{array}$} & $\begin{array}{c}\text { No. of } \\
\text { cases }\end{array}$ & \multicolumn{3}{|c|}{ CORD BLOOD } \\
\cline { 3 - 5 } & $\begin{array}{c}\text { Mean cord } \\
\text { blood } \\
\text { glucose }\end{array}$ & $\begin{array}{c}\text { Standard } \\
\text { Deviation }\end{array}$ & $\begin{array}{c}\text { Significance } \\
\text { (2-tailed) }\end{array}$ \\
\hline $\begin{array}{l}\text { 1 (APGAR } \\
\text { Score } \leq 6)\end{array}$ & $\mathbf{8 0}$ & 89.65 & 22.54 & 0.854 \\
\hline $\begin{array}{l}\text { 2 (APGAR } \\
\text { Score } \geq 7 \text { ) }\end{array}$ & $\mathbf{1 7 0}$ & 90.78 & 19.8 & 0.872 \\
\hline
\end{tabular}

The age of the mother showed no correlation with cord blood sugar levels ( $r$-value $=$ minus 0.0320), but the maternal blood sugar levels showed a weak correlation with cord blood sugar levels (Pearson's co-efficient $=0.330$ ). In the standard ROC curves of the cord blood sugar levels against the fetal distress and cord blood sugar levels against APGAR score at five minutes in the mentioned coordinates, the specificity and sensitivity were maximally close to each other, at a point where the cord blood sugar levels were $86.28 \mathrm{mg} / \mathrm{dl}$ and $87.20 \mathrm{mg} / \mathrm{dl}$ respectively. So, by the above two curves, it was found that cord blood sugar level of a newborn should be at or around $87 \mathrm{mg} / \mathrm{dl}$, for the neonate to be free from any distress.

\section{Discussion}

Although maternal age, an independent risk factor for an adverse pregnancy outcome ${ }^{[12]}$, in the present study no significant change was found in the level of the cord blood glucose with an increase in the maternal age. The study showed no correlation between the cord blood sugar level and the type of delivery, blood pressure of mother, maternal parity and baby's birth weight. Marom R et al reported neonates born via normal vaginal delivery had higher glucose levels than neonates born via elective caesarean section. ${ }^{[13]}$ The mode of delivery did not alter the cord blood glucose levels. This appears that the influence of anaesthetic agents, stress of surgery or labour did not affect cord blood glucose levels blood. But this needs further work up for valid reason of the same.

Sogbanmu and colleagues ${ }^{[11]}$ reported that a correlation of 0.08 between the fetal $\mathrm{pH}$ and the umbilical artery blood sugar. The estimation of the fetal scalp blood $\mathrm{pH}$ is established diagnostic measure of the fetal distress caused by hypoxia. But in the study direct correlation was not found between the fetal distress and the cord blood sugar levels caused by hypoxia, which were similar to our study. The mean maternal blood sugar levels among the study population was found to be $88.16 \pm 10.675$ (SD) $\mathrm{mg} / \mathrm{dl}$, which was poorly associated with the cord blood sugar fluctuations.

In our study it was found that, with proper and timely interventions $97 \%$ of the neonates with APGAR scores of less than 7 at one minute reduced to $32 \%$ at five minutes of life. But there was no correlation between the APGAR scores at one and five minutes of life with the cord blood glucose levels. The difference of the mean between the newborns who had high and low APGAR scores was just 0.7 and therefore the level of glucose hardly varied with high or low APGAR scores.

\section{Conclusion}

Our study concludes that with proper and timely interventions the $97 \%$ of the neonates with APGAR scores of less than 7 at one minute reduced to $32 \%$ at five minutes of life. There was no correlation between the APGAR scores at one and five minutes of life with the cord blood sugar levels. For the of newborns to be free from any complications the cord blood sugar levels must be in and around $87 \mathrm{mg} / \mathrm{dl}$ and the maternal glucose level fluctuations are poorly associated with the cord blood sugar levels.

\section{Recommendations}

The recommendations from the present study are a multicentric studies should be undertaken validation of the correlation between the cord blood sugar levels and APGAR score, The present study showed that the mode of delivery (vaginal delivery caesarean section), did not affect the the cord blood sugar levels. So, labour stress and surgery stress did not affect cord blood glucose levels. Further studies maybe needed in order to ascertain the presence of any such homeostatic mechanism for the cord blood sugar levels, which might help in researches related to diabetes.

\section{References}

1. Melkie $\mathrm{M}$, Yigeremu $\mathrm{M}$, Nigussie $\mathrm{P}$, Teka $\mathrm{T}$, Kinde $\mathrm{S}$. Is the difference in neonatal blood glucose concentration of caesarian and vaginally delivered term infants requiring separated reference 


\section{Karthik et al; Carrelation between APGAR Scare and Card Blaad Glucase Level}

intervals?. BMC research notes. 2012 Dec;5(1):519.

2. Mahapatra M, Raj R. Prediction of neonatal hypoglycemia using cord blood C-peptide and cord $\mathrm{HbA1c}$ in infant of diabetic mother. Indian J Basic Appl Med Res. 2015;4(2):167-71.

3. Casey BM, McIntire DD, Leveno KJ. The continuing value of the Apgar score for the assessment of newborn infants. New England Journal of Medicine. 2001 Feb 15;344(7):467-71.

4. Ahmad MO. Effect of maternal anaemia on apgar score of newborn. Journal of Rawalpindi Medical College. 2015 Dec 30;19(3):239-42.

5. Borruto F, Comparetto C, Wegher E, Treisser A. Screening of fetal distress by assessment of umbilical cord lactate. Clin Exp Obstet Gynecol. 2006;33:219-22.

6. Whittle MJ, Martin WL. Fetal Monitoring in labour. In, Chamberlain Geoffrey, Steer PJ. Tunrbull's Obstetricesarean section, 3rd edition. Churchill Livingstone. 2001;447.

7. Mantzoros, Rifas-Shiman SL, Williams CJ, Fargnoli JL, Kelesidis T, Gillman MW. Cord Blood Leptin and Adiponectin as Predictors of Adiposity in Children at 3 Years of Age: A Prospective Cohort Study. Pediatricesarean section. 2009;123:682-89.
8. APGAR V. A proposal for a new method of evaluation of the newborn infant. Curr Res Anesth Analg. 1953;32:260-67.

9. APGAR V, Holiday DA, James LS, Weisbrot IM, Berrien C. Evaluation of the newborn infant: second report. JAMA. 1958; 168:1985-88.

10. Casey BM, McIntire DD, Leveno KJ. The continuing value of the APGAR score for the assessment of newborn infants. N Engl J Med.2001;344:467-71.

11. Sogbanmu MO, Ajani B. Correlation between fetal $\mathrm{pH}$, cord blood glucose level and APGAR score in a fetal intensive care unitpreliminary report. Afr J Med Med Sci. 1978; 7:17-21.

12. Delbaere I, Verstraelen H, Goetgeluk S, Martens G, De Backer G, Temmerman M. Pregnancy outcome in primiparae of advanced maternal age. Eur J Obstet Gynecol Reprod Biol. 2007;135:41-46.

13. Marom R., Neonatal blood glucose concentrations in caesarean and vaginally delivered term infants Acta Pædiatrica 2010;4:35-41.

Copyright: () the author(s), 2020. It is an open-access article distributed under the terms of the Creative Commons Attribution License (CC BY 4.0), which permits authors to retain ownership of the copyright for their content, and allow anyone to download, reuse, reprint, modify, distribute and/or copy the content as long as the original authors and source are cited.

How to cite this article: Karthik S, Preethi RM, Kumar GV. Study of Correlation between APGAR Score and Cord Blood Glucose Level of Neonates at Tertiary Care Hospital. Asian J. Clin. Pediatr. Neonatol.2020;8(1):37-40.

DOI: dx.doi.org/10.47009/ajcpn.2020.8.1.9

Source of Support: Nil, Conflict of Interest: None declared.

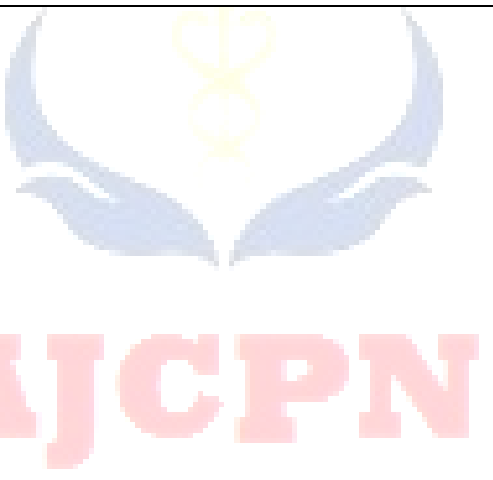

